\title{
Distribution of boron in the rocks of central Nepal Himalaya
}

\author{
Santa Man Rai \\ Department of Geology, Tri-Chandra Campus, \\ Tribhuvan University, Kathmandu, Nepal \\ (E-mail: santamanrai@yahoo.com)
}

\begin{abstract}
Boron content in the rocks of central Nepal Himalaya depends upon the lithology and the grade of metamorphism. The concentration of boron is abundant (up to $322 \mathrm{ppm}$ ) in the metasedimentary rocks of the Lesser Himalaya. There seems to be a rather good correlation between the boron content in the rocks and the grade of metamorphism. The boron content progressively increases from chlorite to garnet isograds, then it systematically decreases in the staurolite \pm kyanite, kyanite and sillimanite isograds, respectively. This trend may be related to the inverse metamorphism associated with movement along the Main Central Thrust.

The Manaslu leucogranite contains very high amount of boron $(950 \mathrm{ppm})$. The enrichment of boron in this rock may be due to the release of boron from the Lesser Himalayan rocks during the partial melting of the Higher Himalayan Crystallines (Tibetan Slab) as a result of the movement along the MCT. Tourmaline from the Manaslu Granite is also highly rich in boron (8460 ppm).
\end{abstract}

\section{INTRODUCTION}

Boron is a lithophile element concentrated in minerals, mainly in danburite $\left[\mathrm{Ca}\left(\mathrm{B}_{2} \mathrm{SiO}_{8}\right)\right]$, datolite $\left[\mathrm{Ca}(\mathrm{OH}) \mathrm{BSiO}_{4}\right]$, tourmaline $\left[(\mathrm{Na}, \mathrm{Fe}, \mathrm{Al}, \mathrm{Li}) \mathrm{Al}_{6} \mathrm{~B}_{3} \mathrm{SiO}_{6} \mathrm{O}_{27}\right]$, axinite $\left[\mathrm{Ca}_{2}(\mathrm{Mn}, \mathrm{Fe}) \mathrm{Al}_{2}\left(\mathrm{BO}_{3}\right)\left(\mathrm{Si}_{4} \mathrm{O}_{12}\right)(\mathrm{OH})\right]$. The abundance of boron is found mostly in marine sediments, argillaceous schist (100-310 ppm) or argillaceous minerals (illite: 400 600 ppm) (Lardrgren 1945, Reynold 1965, Spears 1965, Etheir and Compbell 1977). During the process of chemical weathering, liberation of boron increases and its amount is concentrated within the argillaceous minerals (Spears 1965). The low-grade metamorphic rocks derived from the argillaceous sediments release some amount of boron during metamorphism. In contrast, higher amount of boron is released during the process of high-grade metamorphism (Harder 1975). During the gradual increase in pressure and temperature and activity of fluids related to the regional metamorphism, boron is released and tourmaline mineral is crystallized (Reynold 1965). The crystallization of tourmaline in magmatic rocks is controlled by several factors such as boron content in the magma, pressure, temperature, fugicity and composition of $\mathrm{Al}, \mathrm{Fe}, \mathrm{Mg}, \mathrm{Mn}$, etc (Bernard et al. 1985).

The Miocene leucogranites of the Himalaya are formed due to partial melting of the nelitic rocks of the hot Higher Himalayn Crystallines (Tibetan slab). A large amount of fluids mainly consisting of $\mathrm{B}, \mathrm{F}, \mathrm{CO}_{2}, \mathrm{H}_{2} \mathrm{O}$ were released from the cold Lesser Himalayan rocks during the thrusting along the MCT and partial melting of the Higher Himalayan Crystallines (France-Lanord and Le Fort 1988).

\section{GEOLOGICAL SETTING}

The study area is located in between the longitudes $83^{\circ} 30^{\prime}$ to $85^{\circ} 30^{\prime} \mathrm{E}$ and latitudes $27^{\circ} 5^{\prime}$ to $29^{\circ} 00^{\prime} \mathrm{N}$ (Fig. 1). The area tectonically belongs to the Lesser Himalaya (LH), Higher Himalaya $(\mathrm{HH})$ or Tibetan Slab and Tibetan-Tethys Himalaya (TSH) of central Nepal (Fig. 2). The Miocene Manaslu leucogranite intruding the metasediments of the TibetanTethys Sedimentary Series is also included in this study.

\section{Lesser Himalaya}

The unmetamorphosed and greenschist to lower amphibolite facies metamorphic rocks of the Lesser Himalaya is bordered by the Main Boundary Thrust (MBT) in the south and the Main Central Thrust (MCT) in the north. This unit is divided into the Lower Lesser Himalaya and the Upper

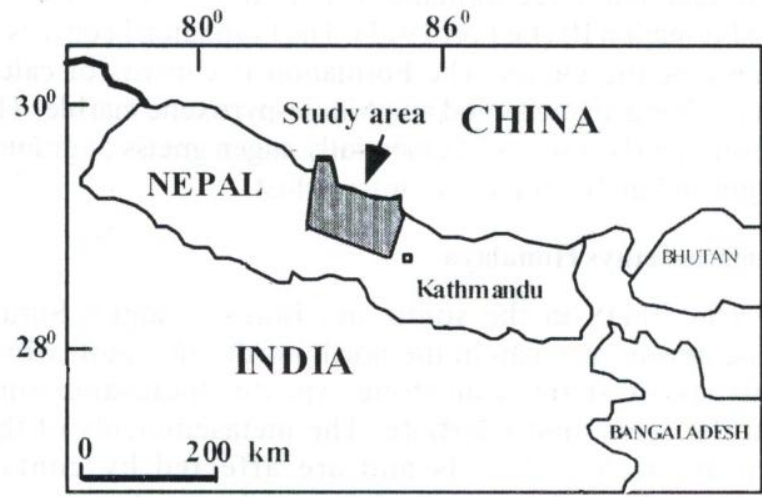

Fig. 1: Location map of the study area. 


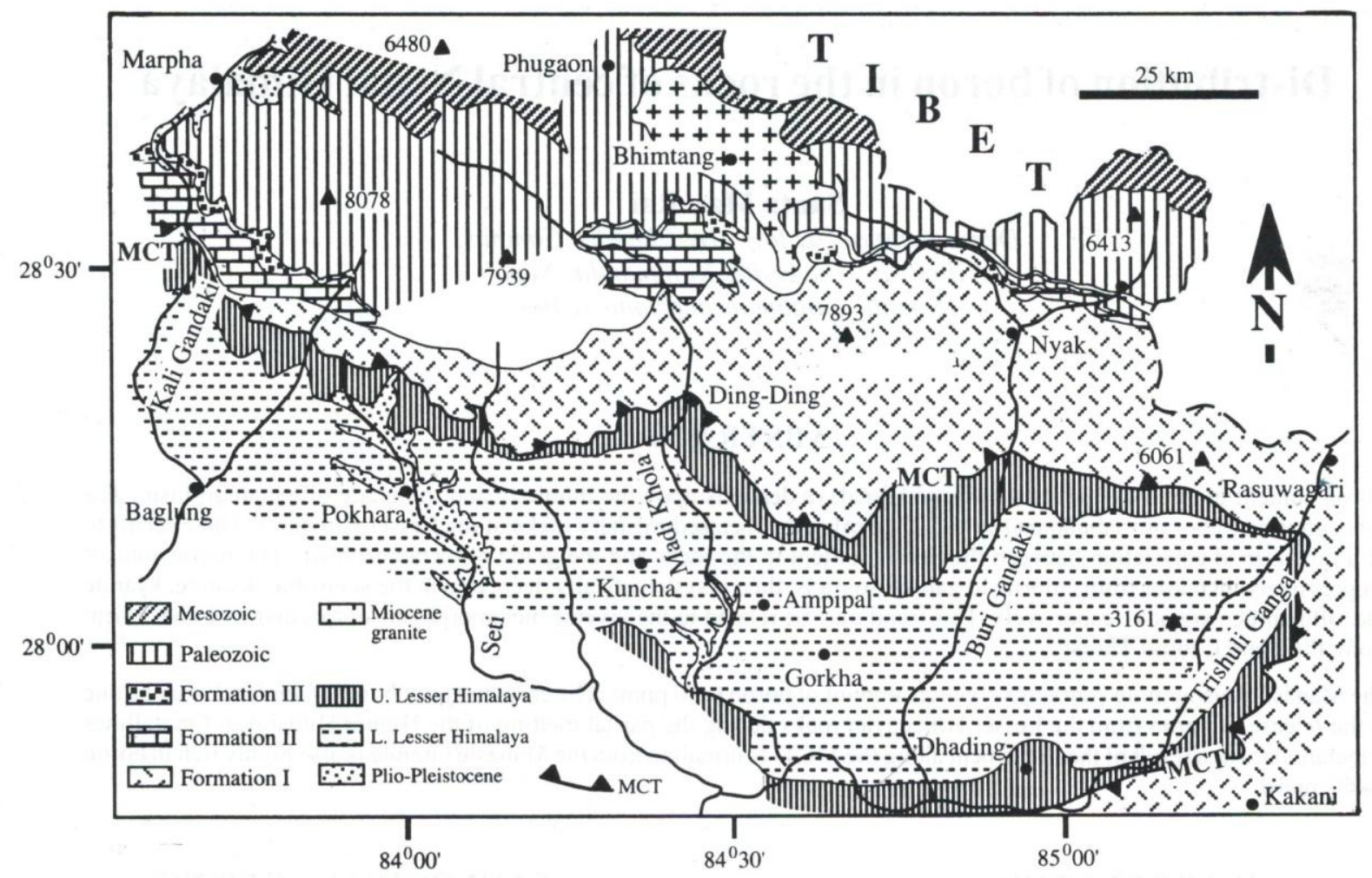

Fig. 2: Geological map of the central Nepal Himalaya (after Colchen et al. 1980, 1986; Rai 2001).

Paleozoic-Mesozoic: Tibetan-Tethys Himalaya, Formation I-III: Higher Himalaya and MCT: Main Central Thrust.

Lesser Himalaya (Le Fort 1975): The Lower Lesser Himalaya consists of the homogenous and thick sequence of phyllite, schist, greywacke and metasandstone, while the Upper Lesser Himalaya comprises mainly of slate, phyllite, schist, metasandstone, quartzite, carbonate rocks and Ulleri-type augen gneiss.

\section{Higher Himalaya (Tibetan Slab)}

This unit tectonically lies in between the MCT in the south and South Tibetan Detachment System (STDS) in the north. It consists of 10-12 km thick succession of amphibolite to granulite facies metamorphic rocks. From bottom to top, it is divided into three formations: Formation I, Formation II and Formation III (Le Fort 1975). The Formation I consists of mainly pelitic gneiss. The Formation II consists of calcic gneiss, banded gneiss and amphibole-pyroxene marble. The Formation III consists of essentially augen gneiss of granitic origin and minor amount of mica schist.

\section{Tibetan-Tethys Himalaya}

The STDS in the south and Indus Tsangpo Suture Zone beyond the map in the north border this unit, which consists of shale, limestone, spilite, metasandstone, marble, schist and quartzite. The metasediments of this unit are rich in fossils and are affected by contact metamorphism that occurred during the emplacement of Miocene Manaslu leucogranite.

\section{Manaslu Leucogranite}

This granite outcrops over an area of about $400 \mathrm{~km}^{2}$. It is elongated in a NW-SE direction with a length of about $30 \mathrm{~km}$ and $13 \mathrm{~km}$ in width. The mineral assemblages of this granite are quartz, Na-rich plagioclase, K-feldspar, muscovite and biotite. This granite is usually tourmaline rich. This leucogranite was generated in response to thickening of the crust (Le Fort 1975, 1981) after the collision between the Indian and Eurasian plates around $50 \mathrm{Ma} . \mathrm{Rb} / \mathrm{Sr}$ and $\mathrm{U} / \mathrm{Pb}$ data suggest that a crystallization age of this granite ranges from 25 to $18 \mathrm{Ma}$ (Daniel et al. 1987), whereas $40 \mathrm{Ar} / 39 \mathrm{Ar}$ suggests a shorter time of emplacement and cooling, around $20 \mathrm{Ma}$ (Copeland et al. 1990).

\section{METAMORPHISM}

The appearance of chlorite, biotite, garnet, staurolite \pm kyanite from lower to higher sections of the Lesser Himalaya records the inverted metamorphic evolution during the MCT movement (Le Fort 1975, Hodges et al. 1996). The retrograde metamorphism on the base of the Higher Himalayan Crystallines due to rapid cooling by conduction and the progressive increase of metamorphic grade in the Lesser Himalaya towards MCT correspond to the MCT movement (Pecher 1978, Pecher and Le Fort 1986). The rapid cooling and decrease in pressure due to tectonic denudation along the STDS resulted in the retrograde metamorphism in 
the upper section of the Higher Himalaya. The grade of the metamorphism decreases from the base to the top of the Tibetan-Tethys Sedimentary Series.

\section{BORON DISTRIBUTION}

The boron, which is an indicator of the circulation of fluids, played an important role during the Himalayan orogeny. The amount of boron was measured in the different rocks from different tectonic units by gamma prompt method. 12 samples from the Lesser Himalaya, 16 samples from the Higher Himalayan Crystallines, 11 samples from the TibetanTethys Sedimentary Series and 22 samples from the Manaslu leucogranites were used for the measurement of boron content. The boron content varies from $1 \mathrm{ppm}$ to more than $300 \mathrm{ppm}$ even in the same formation. The higher amount of boron (maximum $322 \mathrm{ppm}$ ) is found to be concentrated in the Upper Lesser Himalayan rocks. In Manaslu leucogranite the boron content ranges from $12 \mathrm{ppm}$ (sample U470) to 951 ppm (sample DK 028). The distribution of boron with reference to lithology of different formations from different tectonic units is summarized below (Tables 1 and 2).

The boron content in schist of the Lower Lesser Himalaya varies from $18 \mathrm{ppm}$ (sample L 81) to $127 \mathrm{ppm}$ (sample L 82) (Table 1). The conglomeritic metasandstone (243 ppm) contains higher amount of boron than in the pure metasandstone $(18 \mathrm{ppm})$. In the Upper Lesser Himalaya, the boron content in the carbonaceous schist varies according to degree of metamorphism. The rocks from chlorite isograd contains $53 \mathrm{ppm}$, garnet isograd (301 $\mathrm{ppm}$ ) and kyanite isograd (107-171 ppm). The schist of the Upper Lesser Himalaya contains higher amount of boron than the schist of the Lower Lesser Himalaya. This variation in boron content depends on composition of the various types of schists (i.e., calcic, pelitic or carbonaceous). The highest concentration of boron is found in yellow dolomite (322 ppm).
The pelitic gneiss of Formation I of the Higher Himalaya contains very low amount of boron (3-16 ppm) (Table 1). The marble of Formation II has also very low boron content (3-17 ppm). The pure marble contains lower amount of boron than that of the impure marble. The augen gneiss of Formation III has also low boron content (7-17 ppm).

In the Tibetan-Tethys Sedimentary Series, the boron content varies from $7 \mathrm{ppm}$ (pyroxene-marble) to $157 \mathrm{ppm}$ (siliceous marble) (Table 1). Whereas the boron content in the Manaslu leucogranite ranges from $13 \mathrm{ppm}$ to $951 \mathrm{ppm}$ (Table 2).

\section{METAMORPHISM VS. BORON DISTRIBUTION}

In the Lesser Himalaya, there seems to be a rather good correlation between the boron content and the grade of metamorphism (Fig. 3). The boron content seems to progressively increase from chlorite isograd $(17.57 \mathrm{ppm})$ to garnet isograd (322 ppm) (Table 1), then it decreases in the kyanite \pm staurolite isograd ( $83 \mathrm{ppm}$ ) of the Upper Lesser Himalaya and it continues to decrease in the kyanite isograd $(8.3 \mathrm{ppm})$ and sillimanite isograd ( $3.18 \mathrm{ppm})$ in the Formation I of the Tibetan Slab (Fig. 3). This distribution of boron could be related to the inverse metamorphism, related to Main Central Thrust movement. During the low-medium grade metamorphism (chlorite to garnet isogrds) the boron is accumulated by the replacement of aluminum and the aluminum could inversely replace the boron during the high grade metamorphism (kyanite and sillimanite isograds) resulting the low boron content. This distribution shows that the boron bearing minerals, e.g. tourmaline will be destabilized from the certain degree of metamorphism (620$650{ }^{\circ} \mathrm{C}$ ) with increasing temperature and the liberation of boron occurrs mixing with the fluids of rocks (Sisson et al. 1988). In the Tibetan slab, the boron might have liberated and moved with other fluids to the higher structural section resulting in the lower amount of boron.

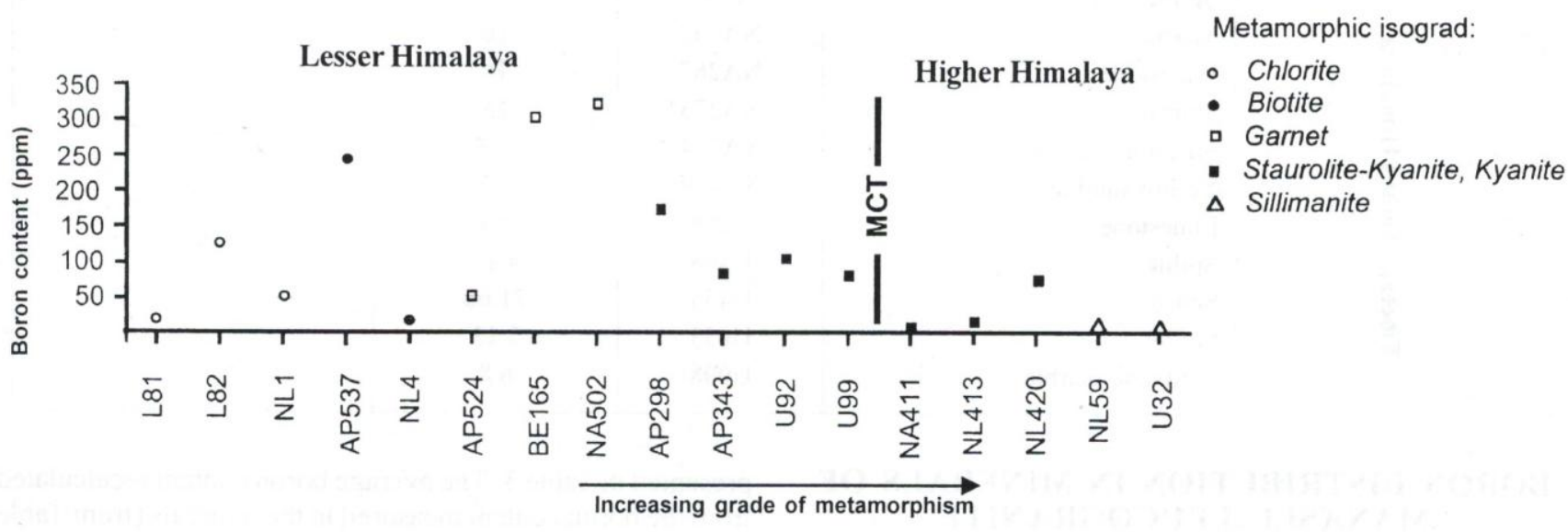

Fig. 3: Boron content in the different metamorphic isograds (from chlorite to sillimanite) in the Lesser Himalaya and Higher Himalayan Crystallines (Formation I). L81: Sample no., MCT: Main Central Thrust. 
Table 1: Boron content (in ppm) in different rocks belonging to different tectonic units of central Nepal Himalaya

\begin{tabular}{|c|c|c|c|c|c|}
\hline \multicolumn{2}{|c|}{ Tectonic unit } & $\begin{array}{c}\text { Lithology } \\
\end{array}$ & Sample No. & Boron (ppm) & Metamorphic isograd \\
\hline \multirow{2}{*}{ 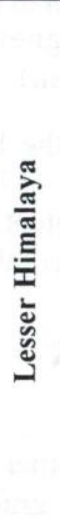 } & 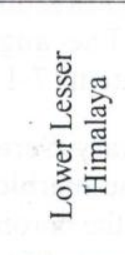 & $\begin{array}{l}\text { Greywacke } \\
\text { Schist } \\
\text { Carbonaceous schist } \\
\text { Conglomeritic greywacke } \\
\text { Schist } \\
\text { Schist }\end{array}$ & $\begin{array}{c}\text { L81 } \\
\text { L82 } \\
\text { NL1 } \\
\text { AP537 } \\
\text { NL4 } \\
\text { AP524 }\end{array}$ & $\begin{array}{c}17.57 \\
127 \\
52.81 \\
242.86 \\
18.25 \\
51.51\end{array}$ & $\begin{array}{l}\text { Chlorite } \\
\text { Chlorite } \\
\text { Chlorite } \\
\text { Biotite } \\
\text { Biotite } \\
\text { Garnet }\end{array}$ \\
\hline & 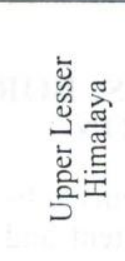 & $\begin{array}{l}\text { Carbonaceous schist } \\
\text { Yellow dolomite } \\
\text { Carbonaceous schist } \\
\text { Schist } \\
\text { Carbonaceous schist } \\
\text { 2Mica-Garnet-Stouralite schist }\end{array}$ & $\begin{array}{l}\text { BE165 } \\
\text { NA502 } \\
\text { AP298 } \\
\text { AP343 } \\
\text { U92 } \\
\text { U99 }\end{array}$ & $\begin{array}{c}301 \\
322 \\
170.8 \\
84.57 \\
107 \\
83\end{array}$ & $\begin{array}{l}\text { Garnet } \\
\text { Garnet } \\
\text { Kyanite } \\
\text { Staurolite + Kyanite } \\
\text { Kyanite } \\
\text { Staurolite-Kyanite }\end{array}$ \\
\hline \multirow{3}{*}{ 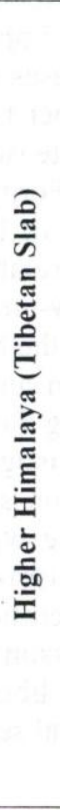 } & चี & $\begin{array}{l}\text { 2Mica-Kyanite gneiss } \\
\text { Kyanite-gneiss } \\
\text { Kyanite - banded gneiss } \\
\text { Sillimanite-gneiss } \\
\text { Sillimanite - gneiss }\end{array}$ & $\begin{array}{l}\text { NA411 } \\
\text { NL413 } \\
\text { NL420 } \\
\text { NL59 } \\
\text { U32 }\end{array}$ & $\begin{array}{c}8.3 \\
15.1 \\
77 \\
4.6 \\
3.18\end{array}$ & $\begin{array}{l}\text { Kyanite } \\
\text { Kyanite } \\
\text { Kyanite } \\
\text { Sillimanite } \\
\text { Sillimanite }\end{array}$ \\
\hline & 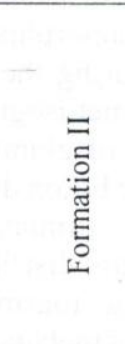 & $\begin{array}{l}\text { Marble } \\
\text { Marble } \\
\text { Pyroxene-marble } \\
\text { Pure marble } \\
\text { Phlogopite marble } \\
\text { Muscovite-Pyroxene-marble } \\
\text { Pure marble } \\
\text { Graphitic marble }\end{array}$ & $\begin{array}{c}\text { D5 } \\
\text { D87 } \\
\text { NA132 } \\
\text { NA141 } \\
\text { NA142 } \\
\text { NA143 } \\
\text { NA146 } \\
\text { NA148 }\end{array}$ & $\begin{array}{c}12 \\
11 \\
17 \\
3.9 \\
6.4 \\
7.3 \\
3 \\
14\end{array}$ & \\
\hline & 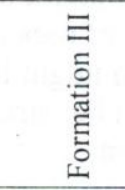 & $\begin{array}{l}\text { Augen gneiss } \\
\text { Augen gneiss } \\
\text { Augen gneiss }\end{array}$ & $\begin{array}{c}\text { D77 } \\
\text { NL478 } \\
\text { U925 }\end{array}$ & $\begin{array}{c}17 \\
11.9 \\
6.9\end{array}$ & \\
\hline & 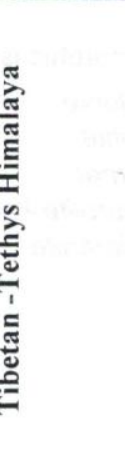 & $\begin{array}{l}\text { Spilite } \\
\text { Marble } \\
\text { Limestone } \\
\text { Marble } \\
\text { Siliceous marble } \\
\text { Yellow marble } \\
\text { Limestone } \\
\text { Spilite } \\
\text { Schist } \\
\text { Spilite } \\
\text { Pyroxene-marble }\end{array}$ & $\begin{array}{c}\text { N4 } \\
\text { NA162 } \\
\text { NA267 } \\
\text { NA273 } \\
\text { NA274 } \\
\text { NL449 } \\
\text { U258 } \\
\text { U408 } \\
\text { U453 } \\
\text { U653 } \\
\text { U998 }\end{array}$ & $\begin{array}{c}1.3 \\
16 \\
16 \\
15 \\
157 \\
17 \\
56 \\
4.13 \\
71.66 \\
3.13 \\
6.8\end{array}$ & \\
\hline
\end{tabular}

\section{BORON DISTRIBUTION IN MINERALS OF} MANASLU LEUCOGRANITE

Distribution of boron content in different minerals (tourmaline, biotite, muscovite, potassic feldspar, plagioclase and quartz) from ten samples of the Manaslu leucogranite is presented in Table 3. The average boron content recalculated from the boron content measured in the minerals (from Table 3 ) is presented in Fig. 4 and Table 4 . Tourmaline has very high boron content (approximately $8500 \mathrm{ppm}$ ). Biotite and muscovite have $<750 \mathrm{ppm} 70-80 \mathrm{ppm}$ respectively (Table 4). As biotite contains tourmaline inclusions, the high value of 
Table 2: Boron content ( $\mathrm{ppm}$ ) from the Manaslu leucogranite

\begin{tabular}{|c|c|c|}
\hline Granite & Sample No. & ppm \\
\hline \multirow{22}{*}{ 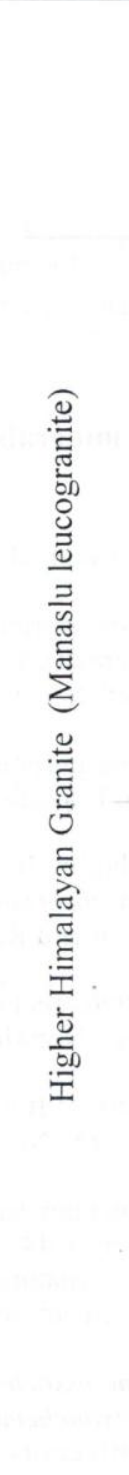 } & D16 & 60 \\
\hline & D22 & 120 \\
\hline & DK157 & 34 \\
\hline & DK195 & 103.1 \\
\hline & DK28 & 951 \\
\hline & DK43 & 100 \\
\hline & DK45 & 43 \\
\hline & DK53 & 16.6 \\
\hline & DK54 & 32.5 \\
\hline & DK59 & 20.9 \\
\hline & $\mathrm{T} 17$ & 160 \\
\hline & U172 & 820 \\
\hline & U277 & 30 \\
\hline & U330 & 820 \\
\hline & U464 & 390 \\
\hline & U476 & 13 \\
\hline & $\mathrm{U} 476 \mathrm{~A}$ & 15.3 \\
\hline & U476B & 15.2 \\
\hline & U697 & 663.7 \\
\hline & U743 & 248 \\
\hline & $\mathrm{X} 12$ & 131 \\
\hline & X77 & 300 \\
\hline
\end{tabular}

boron is expected. Muscovite generally contains low amount of boron (Harder 1975, Reynold 1965). Potash feldspar, plagioclase and quartz have also very low concentration of boron $(<10 \mathrm{ppm})$ (Table 4$)$.

The Manaslu leucogranite is believed to have formed due to the partial melting of the pelitic rocks of the hot Higher Himalayan Crystallines (France-Lanord and Le Fort 1988). The boron has probably played an important role during the anatexis process (Le Fort 1987). The boron content of the Manaslu granite is very high as compared to Clarke value (30 ppm) for granite (Harder 1975).
Table 3: Boron content (ppm) from different minerals of the Manaslu leucogranite

\begin{tabular}{|c|c|c|}
\hline Sample No. & Mineral & ppm \\
\hline D22 & Muscovite & 59.7 \\
\hline D65 & Muscovite & 48.6 \\
\hline DK28 & Potassic feldspar & 12.9 \\
\hline DK28 & Muscovite & 142.7 \\
\hline DK28 & Plagioclase & 6.6 \\
\hline DK28 & Plagioclase+Quartz & 10.6 \\
\hline DK28 & Tourmaline & 8229.4 \\
\hline U315 & Potassic feldspar & 3.4 \\
\hline U315 & Muscovite & 72.2 \\
\hline U315 & Quartz & 2.3 \\
\hline U476 & Biotite & 21.4 \\
\hline U476 & Potassic feldspar & 10.7 \\
\hline U476 & Muscovite & 76.4 \\
\hline U476 & Plagioclase & 10.1 \\
\hline U697 & Biotite & 456.3 \\
\hline U697 & Muscovite & 91.7 \\
\hline U697 & Tourmaline & 8488.2 \\
\hline U743 & Biotite & 94.1 \\
\hline U743 & Muscovite & 85.1 \\
\hline U743 & Tourmaline & 8662.6 \\
\hline $\mathrm{X} 10$ & Muscovite & 59.1 \\
\hline $\mathrm{X} 12$ & Biotite & 2781.4 \\
\hline $\mathrm{X} 77$ & Biotite & 359.2 \\
\hline $\mathrm{X} 77$ & Potassic feldspar & 11.1 \\
\hline $\mathrm{X} 77$ & Muscovite & 75.2 \\
\hline $\mathrm{X} 77$ & Plagioclase + Quartz & 9.6 \\
\hline X77 & Quartz & 9 \\
\hline
\end{tabular}

\section{CONCLUSIONS}

Boron distribution in formations of different tectonic units of the central Nepal Himalaya is variable. It is found to depend upon the lithology and the grade of metamorphism. The variation in lithology can control the distribution of boron, but their distribution manner is unsystematic. The concentration of boron is higher in the rocks of the Lesser Himalaya. In the Lesser Himalaya, there seems to be a rather 
Table 4: Average boron content (ppm) of different minerals recalculated from Table 3

\begin{tabular}{|l|c|}
\hline \multicolumn{1}{|c|}{ Mineral } & (ppm) \\
\hline Quartz & 5.65 \\
\hline Potassic feldspar & 8.35 \\
\hline Plagioclase & 9.5 \\
\hline Plagioclase+Quartz & 10.1 \\
\hline Muscovite & 78.97 \\
\hline Biotite & 742.48 \\
\hline Tourmaline & 8460.07 \\
\hline
\end{tabular}

good correlation between the boron content and the grade of metamorphism. The boron content systematically increases from chlorite to garnet isograds, then it starts decreasing in the staurolite \pm kyanite isograd of the Upper Lesser Himalaya and continues to decrease in the kyanite and sillimanite isograds in the Formation I of the Higher Himalayan Crystallines. This distribution of boron could be related to the inverse metamorphism, related to the Main Central Thrust movement.

The enrichment of boron in Manaslu leucogranite might have occurred due to the release of boron from the Lesser Himalayan rocks during the partial melting of the Higher Himalayan Crystallines (Tibetan Slab) as a result of the movement along the MCT.

\section{ACKNOWLEDGEMENTS}

I would like to express my special thanks to Drs. P. Le Fort, A. Pecher, F. Debon, S. Guillot and B. N. Upreti for their valuable suggestions, comments and helps during the preparation of this paper. I am grateful to the Government of France for providing me a scholarship to carry out research leading to DEA at the University of Joseph Fourier, Grenoble, France.

\section{REFERENCES}

Bernard, F., Moutou, P., and Pichavant, M., 1985, Phase relations of tourmaline granites and the significance of tourmaline in silicic magma. Jour. Geol., v. 93, pp. 271-291.

Colchen, M., Le Fort, P., and Pêcher, A., 1980, Carte géologique Annapurna-Manaslu-Ganesh, Himalaya du Nepal. Scale 1:200000. Nepal Central.

Colchen, M., Le Fort, P., and Pêcher, A., 1980, Recherches géologiques dans l'Himalaya du Nepal. Annapurna, Manaslu, Ganesh. Edit. C.N.R.S., Paris, 136 p.

Copeland, P., Harrison, T. M., and Le Fort, P., 1990, Age and cooling of the Manaslu granite: implications for Himalayan tectonics. Jour. Volc. Geotherm. Res., v. 44, pp. 33-50.

Daniel, C., Vidal, P., Fernandez, A., and Le Fort, P., 1987, Isotopic study of the Manaslu granite (Himalaya, Nepal): Inferences

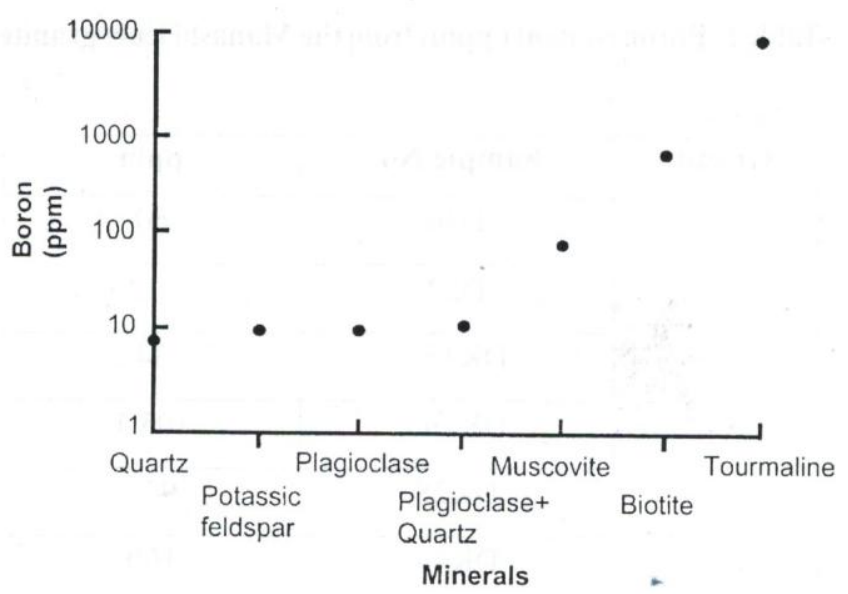

Fig. 4: Average Boron content of different minerals in Manaslu Granite (from Table 3)

on the age and source of Himalayan leucogranites. Contr. Miner Petrol. v. 96 , pp. $78-82$.

Etheir, V. and Compbell, F. A., 1977, Tourmaline concentrations in Proterozoic sediments of the southern Cordillera of Canada and their economic significance. Canad. Jour. Earth Sci., v. 14, pp. 2348-2363.

France-Lanord, C. and Le Fort, P., 1988, Crustal melting and granite genesis during the Himalayan collision orogenesis. Trans. Royal Soc. Edin.: Earth Sci., v. 79, pp. 183-195

Harder, H., 1975, Contribution to geochemistry of boron. Boron in minerals and igneous rocks. In: Walker, T. (ed.), Geochemistry of Boron. St, roudsburg, Pa, Dowden, Hatchinson and Ross, v. 23 , pp. $47-63$

Hodges, K. V., Parrish, R. R., and Searle, M. P., 1996, Tectonic evolution of the central Annapurna Range, Nepalese Himalayas. Tectonics, v. 15, pp. 1264-1291.

Lardrgren, S., 1945, Contribution to the geochemistry of Boron Arkiv For Kemi, Mineralogi Och Geologi., v. 19A, No 26 , pp. $1-31$

Le Fort, P., 1975, Himalaya: the collided range. Present knowledge of the continental arc. Amer. Jour. Sci., v. 75A, pp. 1-44.

Le Fort, P., 1981, Manaslu leucogranite: a collision signature of the Himalaya. A model for its genesis and emplacement. Jour. Geophys. Res., v. 86, pp. 10545-10568.

Pêcher, A., 1978, Deformations and metamorphisme associes a une zone de cisaillement: Exemple du grand chevauchement central Himalaya $(M C T)$. These d'Etat. University of Grenoble, France, $354 \mathrm{p}$.

Pêcher, A. and Le Fort, P., 1986, The metamorphism in central Himalaya, its relations with the thrust tectonics. In: "Evolution des domains orogeniques d'Asie meridionale (de la Turquie a l'Indonesie)", P. Le Fort, M. Colchen and C. Montenat eds., Sci. Terre, Mem., v. 47, pp. 285-309.

Rai, S. M., 2001, Geology, geochemistry, and radiochronology of the Kathmandu and Gosainkund Crystalline nappes, central Nepal Himalaya. J. Nepal Geol. Soc. Special Pub., v. 25. pp. $135-155$.

Reynold, R. C., 1965, The concentration of boron in Precambrian seas. Geochim. Acta, v. 29, pp. 1-16.

Sisson, V. B., Clossman, C. E., and Leeman, W. P., 1988, Boron loss during low pressure progressive metamorphism of Central Maine and Southern Chugach Mountains, Alaska. Abstract, A342.

Spears, D. A., 1965, Boron in some Carboniferous sedimentary rocks. Geochim. Cosmochim. Acta. v. 29, pp. 315-328. 